\begin{tabular}{|c|c|c|}
\hline Dinamika Journal, Vol. 1 No. 4, 2019 \\
ISSN ONLINE : 2686-2158
\end{tabular}

\title{
PENGAWASAN BAHAN BAKU INDUSTRI PENGOLAHAN BEKICOT PT. KEONG NUSANTARA ABADI (WONG COCO) SERTA PEMBERDAYAAN PEREMPUAN DI DESA MOJOAYU KECAMATAN PLEMAHAN KABUPATEN KEDIRI
}

\author{
Achmad Wais', Yogi Putranto', Hawi Fia Maraputra', Bayu Indra Patria1 \\ ${ }^{1}$ Pengawas Perikanan Stasiun Pengawasan Sumberdaya Kelautan dan Perikanan, Cilacap \\ Jalan Bima No. 104 A Kebonmanis Cilacap Utara Cilacap, Indonesia \\ Corresponding author: yogiputranto30@gmail.com
}

Received 16 October 2019; Accepted 12 December 2019; Available online 19 December 2019

\begin{abstract}
Abstrak
Bekicot (Achantina fulica) merupakan salah satu bahan baku utama dari produk ekspor "bekicot dalam olahan garam" Industri PT. Keong Nusantara Abadi berada di Desa Mojoayu Kecamatan Plemahan Kabupaten Kediri. Keberadaan stock bahan baku bekicot tersebut menjadi penentu industry tersebut. Walaupun PT. Keong Nusantara Abadi juga melakukan diversifikasi usaha berupa nata de coco. Selain itu, industri tersebut juga melibatkan kaum perempuan dalam proses pengolahan. Hingga saat ini belum ada penelitian terhadap analisis stock bahan baku serta produksi bekicot untuk kebutuhan industri PT PT. Keong Nusantara Abadi dan peningkatan pendapatan perempuan Desa Mojoayu Kecamatan Plemahan Kabupaten Kediri. Survey telah dilakukan di desa Desa Mojoayu Kecamatan Plemahan, Kabupaten, Kediri.dengan menggunakan metode wawancara. Penelitian dilakukan dengan Responden yaitu kepala bidang produksi, kepala bidang quality control dan bagian administrasi PT. Keong Nusantara Abadi (Wong Coco). Teknik analisis data dalam penelitian ini yaitu deskriptif. Hasil penelitian menunjukkan tingkat kebutuhan bahan baku bekicot selama periode produksi adalah 450 ton/tahun. Kesediaan bahan baku bekicot ini sangat bergantung pada musim penghujan. Keberadaan industri pengolahan bekocot ini menjadi salah satu faktor yang memberikan perubahan pendapatan kaum perempuan di Desa Mojoayu Kecamatan Plemahan Kabupaten Kediri.
\end{abstract}

Kata Kunci: bahan baku, Achantina fulica, pemberdayaan perempuan

\begin{abstract}
Snail (Achantina fulica) is one of the main raw materials from the export product of "snail in processed salt" Industry PT. The Immortal Conch of Nusantara depends on Mojoayu Village, Plemahan District, Kediri Regency. The existence of the snail raw material stock determines the industry. Even though PT. Keong Nusantara Abadi also diversifies its business into nata de coco. In addition, this industry also deals with women in the processing process. Until now there has been no research on the analysis of raw material stock and snail production for the industrial needs of PT. Nusantara Abadi Conch and Increased Income of Mojoayu Village, Plemahan District, Kediri Regency. The survey was conducted in the village of Mojoayu in the district of Plemahan, regency, Kediri. By using
\end{abstract}


the interview method. Research conducted with Respondents namely the head of production, the head of quality control and administration of PT. The Immortal Conch (Wong Coco). The data analysis technique in this research is descriptive. The results showed the level of snail raw material requirements during the production period was 450 tons / year. The availability of snail raw materials is very reliable in the rainy season. The existence of the snail processing industry is one of the factors that provides a change in the income of women in Mojoayu Village, Plemahan District, Kediri Regency.

Keywords: raw materials, Achantina fulica, women's empowerment

\section{PENDAHULUAN}

Dalam Undang-Undang Nomor 31 Tahun 2004 Tentang Perikanan sebagaimana diubah dan ditambah menjadi Undang-Undang Nomor 45 Tahun 2009 bahwa bekicot (Mollusca) juga dapat digolongkan ke dalam jenis ikan Bekicot merupakan hewan invertebrata dengan tubuh lunak dari kelas Gastropoda. Bekicot mempunyai cangkang yang besar runcing berwarna coklat dan mempunyai pola garis, padat berbentuk pyramid (seperti kerucut) dengan pola spiral (lilitan seperti sekrup) dan dasar cangkang yang membulat (Thiengo, 2010). Cangkang bekicot dewasa mempunyai panjang sekitar $10 \mathrm{~cm}$ sampai $12 \mathrm{~cm}$, lebar 4-5 cm dan berat 100-120 gr. Fungsi cangkang selain sebagai rumah juga untuk mempertahankan diri dari musuh dan untuk memperkecil penguapan tubuhnya (Hironymus, 2011).

Bekicot menggunakan bagian bawah tubuhnya (perut) untuk berjalan, menggunakan paru-paru untuk bernafas sehingga dimasukkan ke dalam ordo Pulmonata. Bekicot dapat hidup di air laut, air tawar dan di darat, umur bekicot dapat mencapai 10 tahun, dengan rata-rata usia hidup 5-7 tahun (Venette, 2013). Sebagai bahan makanan, nilai gizi bekicot cukup tinggi. Kandungan protein dalam 100 gram daging bekicot ada 57,08 gram, 3,34 gram lemak, 2,05 gram serat besar, 13,8 abu, 1,58 gram kalsium dan 1, 48 gram pospor. (Chaves, 1997 dalam Sovia Emmy. 1980).

Bekicot yang pada awalnya diburu dan dibunuh untuk pakan tambahan itik, sekarang diburu dan dikumpulkan untuk disetor kepada perusahaan pengekspor bekicot. Hal ini terjadi karena adanya permintaan pasar luar negeri terutama Perancis.

PT Keong Nusantara Abadi adalah salah satu industri yang bergerak dalam produksi ekspor dari olahan bekicot. Industri ini terletak di Jalan Raya Bogo Kunjang, Desa Mojoayu, Kecamatan Plemahan, Kabupaten Kediri. Industri ini mulai berdiri pada tahun 2002 dengan luas $27 \mathrm{Ha}$. Pemilihan lokasi di dekat jalan raya dikarenakan kondisi wilayah yang mendukung, ketersediaan tenaga kerja, dan mempermudah dalam distribusi barang dalam kegiatan pemasaran.

Desa Mojoayu memiliki luas wilayah $154.11 \mathrm{Ha}$ dengan luas lahan pertanian sawah seluas $103 \mathrm{Ha}$ dan lahan kering seluas $43 \mathrm{Ha}$. Jumlah penduduk sebanyak 2075, dengan mayoritas bekerja sebagai petani sebanyak 315 jiwa dan buruh tani sebanyak 414 jiwa (Data Umum Desa Mojoayu, 2017 : 2). Desa Mojoayu pada umumnya bertumpu pada sektor agraris namun sejak keberadaan industri, mengakibatkan perubahan pada masyarakat sekitar.

Stock bahan baku bekicot tentu menjadi topik menarik untuk dibahas dikarenakan menurut penulis sekarang bekicot sulit untuk didapatkan. Selain itu, perubahan pada masyarakat karena keberadaan industri dapat mengarah pada perubahan yang bersifat positif maupun negatif. Perubahan yang bersifat positif seperti perubahan status sosial, peningkatan pendapatan. Perubahan negatif seperti renggangnya hubungan sosial dalam masyarakat, dan hilangnya tradisi-tradisi dalam masyarakat. Setiap industri memberikan 
efek perubahan yang berbeda-beda terhadap masyarakat sekitarnya. Keberadaan industri pengolahan bekicot dirasa.membawa beberapa perubahan pada masyarakat, terutama perubahan pendapatan dan ekonomi kaum perempuan pada masyarakat di Desa Mojoayu. Berdasarkan latar belakang permasalahan tersebut peneliti bermaksud melakukan penelitian dengan judul "Pengawasan Bahan Baku Industri Pengolahan Bekicot Pt. Keong Nusantara Abadi (Wong Coco) Serta Pemberdayaan Perempuan Di Desa Mojoayu Kecamatan Plemahan Kabupaten Kediri”. Tujuan penelitian ini untuk mengetahui karakteristik industri pengolahan bekicot, perubahan kondisi sosial dan ekonomi masyarakat Desa Mojoayu Kecamatan Plemahan Kabupaten Kediri dengan keberadaan industri tersebut.

\section{MATERI DAN METODE PELAKSANAAN}

Jenis penelitian ini adalah penelitian survey dengan menggunakan metode wawancara. Penelitian dilakukan di Desa Mojoayu Kecamatan Plemahan Kabupaten Kediri. Responden dalam penelitian ini antara lain yaitu kepala bidang produksi, kepala bidang quality control dan bagian administrasi PT. Keong Nusantara Abadi (Wong Coco). Teknik analisis data dalam penelitian ini yaitu deskriptif. Penelitian dilaksakakan pada tanggal 8 Oktober sampai dengan 9 Oktober 2019.

Sumber data dalam penelitian ini menggunakan sumber data primer dan data sekunder. Data primer diperoleh dari hasil wawancara terhadap responden, sedangkan data sekunder diperoleh dari pustaka. Teknik analisis data yang digunakan dalam penelitian ini menggunakan teknik persentase dengan cara memberikan persentase pada setiap kriteria kemudian mendeskripsikannya.

\section{HASIL PENELITIAN}

\subsection{Karakteristik industri}

Karakteristik merupakan ciri khusus yang membedakan antara industri pengolahan bekicot dengan industri lain. Karakteristik industri dapat dilihat dari alasan pendirian industri di Desa Mojoayu Kecamatan Plemahan Kabupaten Kediri. Industri Pengolahan bekicot mulai berdiri dan beroperasi pada tahun 2002 di Desa Mojoayu Kecamatan Plemahan Kabupaten Kediri. Industri pengolahan bekicot merupakan industri yang bergerak di bidang makanan kaleng untuk keperluan ekspor. Industri pengolahan bekicot, di bangun di Desa Mojoayu Kecamatan Plemahan Kabupaten Kediri dikarenakan beberapa hal diantaranya.

\section{a. Lokasi yang strategis}

Industri pengolahan bekicot berdiri di wilayah yang strategis yaitu di jalan BogoKunjang yang notabene merupakan jalan alternatif Kediri-Surabaya. Pemilihan lokasi ini diharapakan mampu mempermudah distribusi barang dari hasil produksi industri. Pemilihan pembangunan lokasi industri di Desa Mojoayu juga dikarenakan adanya sebuah sungai yang mengalir yang dibutuhkan untuk kebutuhan kegiaran industri.

b. Potensi Penjualan

Potensi penjualan bekicot sebagai produk olahan cukup cerah, saat ini di Kabupaten Kediri sebagai sentra awal bekicot ini diternakkan telah tumbuh pengrajin makanan yang dijual secara luas baik berupa keripik bekicot, sate bekicot maupun sambal goreng bekicot. Lingkungan Desa Mojoayu merupakan lingkungan yang memiliki penyinaran matahari yang tinggi sehingga kondisi suhu di lingkungan tersebut dalam kategori yang cukup hangat yaitu 28-32 ${ }^{\circ} \mathrm{C}$. Kondisi lingkungan yang memenuhi syarat banyak ditemukan bekicot maka industri memilih Desa Mojoayu Kecamatan Plemahan sebagai lokasi industri. 
c. Sistem kerjasama dengan masyarakat Karakteristik yang membedakan industri

Pengolahan bekicot dengan industri lain adalah sitem kerjasama dengan masyarakat sekitar. Masyarakat dapat menjadi supplier bekicot dengan standar quality yang ditentukan oleh industry. Jika masyarakat memilik standar bekicot yang akan dimasukkan kedalam industry untuk diolah, pihak industry akan melakukan survey lokasi untuk kemudian melakukan kegiatan Memorandum of Understanding (MOU) dengan supplier tersebut. Sistem kerjasama dengan masyarakat dari industry menjadi pembeda dengan industri lain karena memberikan keuntungan pada masyarakat.

\subsection{Analisis stock bahan baku industri}

Sampai saat ini, daging bekicot sampai saat ini (Khusus daerah Kediri) diperjual belikan dalam bentuk bekicot olahan tradisional seperti sate bekicot, keripik bekicot dan lain - lain, sehingga kompetisi untuk mendapatkan daging bekicot dengan pengolahan tradisonal sangatlah tinggi.

Berdasarkan hasil penelitian, terlihat bahwa kebutuhan stock bahan baku minimal di PT administrasi PT. Keong Nusantara Abadi (Wong Coco) terlihat pada tabel 1.

Tabel 1. Perhitungan stock minimal bekicot hidup PT. Keong Nusantara Abadi (Wong Coco)

Penghitungan Stock Minimal Bekicot Hidup

- Produksi dalam setahun adalah selama 3 bulan

- Produksi paling minimal 5 ton/hari

- Jika produksi dilakukan selama 3 bulan maka stock bahan baku yang diperlukan : 5 ton $\times 30$ hari $\times 3$ bulan $=450$ ton $/ 3$ bulan

Dari hasil penelitian bahwa selama proses produksi diperlukan 450 ton bekicot hidup. Kebutuhan stock bekicot sangat tergantung dari factor musim serta banyaknya competitor dalam industry tersebut diantaranya beberapa perusahaan di Jawa Timur dan Jawa Tengah yang bergerak dalam usaha yang pengolahan bekicot. Komptetitor utama justru dikarenakan usaha pengolahan tradisonal di dusun Jengkol desa Plosokidul, kecamatan Plosoklaten, Kabupaten Kediri. Usahanya meliputi sate bekicot, sambal goreng bekicot, dan keripik bekicot. Usaha tersebut mengambil bekicot dengan berbagai ukuran, sementara bekicot dari industry harus memperhatikan grade/ukuran bekicot, area penangkapan bekicot serta bebas tidaknya bekicot dari pestida maupun logam berat. Ukuran standar yang diambil perusahaan adalah $6-12 \mathrm{~cm}$.

\subsection{Pemasaran bekicot}

Berdasarkan penelitian bahwa produk PT. Keong Nusantara Abadi berupa olahan bekicot dalam larutan garam dipasarkan ke Negara Perancis, Singapura, Amerika Serikat dan Jepang tanpa lebel perusahaan kemudian di brand ulang sesuai dengan permintaan imprortir.

\subsection{Perubahan kondisi sosial kaum perempuan}

Keberadaan industri pengolahan bekicot di Desa Mojoayu Kecamatan Plemahan, memberikan perubahan pada kondisi sosial pada masyarakat. Kondisi sosial dikategorikan dalam perubahan sikap, perubahan hubungan sosial dan kontribusi industri terhadap perkembangan desa. Perubahan kondisi sosial masyarakat Desa Mojoayu dengan keberadaan industri pengolahan bekicot dapat dirincikan dengan perubahan sikap kaum perempuan. Perubahan sikap kaum perempuan tersebut berupa perubahan terhadap pola 
pikir masyarakat dan perubahan gaya hidup (konsumtif) dengan keberadaan industri pengolahan bekicot. Hasil penelitian menunjukkan bahwa dari karyawan PT Keong Nusantara Abadi sebanyak 130 orang $70 \%$ terdiri atas kaum perempuan. Berdasarkan data tersebut, maka dengan adanya perusahaan tersebut maka 91 perempuan dari Desa Mojoayu Kecamatan Plemahan mengalami perubahan gaya hidup (konsumtif).

\subsection{Perubahan pendapatan kaum perempuan}

Perubahan kondisi ekonomi meliputi perubahan pendapatan dan pengeluaran selama satu bulan. Perubahan pendapatan bersih adalah pendapatan bersih selama satu bulan dari pekerjaan pokok dan sampingan dengan keberadaan industri pengolahan.

Perubahan pendapatan masyarakat dikategorikan dalam kondisi pendapatan masyarakat dengan keberadaan industry pengolahan bekicot, pendapatan masyarakat sebelum keberadaan industri pengolahan bekicot, dan jumlah peningkatan pendapatan dengan keberadaan industri pengolahan bekicot. Hasil penelitian menunjukkan bahwa perubahan pendapatan bersih kaum perempuan Desa Desa Mojoayu Kecamatan Plemahan, yang bekerja di PT Keong Nusantara Abadi menunjukan peningkatan pendapatan dengan persentase sebesar $45 \%$. Jumlah peningkatan pendapatan masyarakat yaitu Rp. 1.000.000,00 - Rp. 3.000.000,00. Pendapatan masyarakat dalam kategori tinggi jika berpatokan dengan standart UMR Kabupaten Kediri yang berkisar pada Rp. 1.800.000,00. Penelitian ini sesuai dengan penelitian yang dilakukan oleh Sigmi (2018:78) yang menyatakan bahwa keberadaan industri berpengaruh pada peningkatan pendapatan masyarakat.

Pengeluaran kaum perempuan dalam penelitian ini, dilihat dari kondisi pengeluaran masyarakat setelah keberadaan industri pengolahan bekicot. Pendapatan dan pengeluaran adalah sesuatu yang saling berkaitan semakin tinggi pendapatan maka semakin tinggi pengeluaran. Tingkat pengeluaran masyarakat sebelum keberadaan industri pengolahan bekicot dalam kategori sangat rendah yaitu $<\mathrm{Rp}$. 1.000.000,00 per bulan. Dengan keberadaan industri tingkat pengeluaran masyarakat mengalami perubahan dengan jumlah Rp. 1.000.000,00 - Rp. 3.000.000,00.

Perubahan pengeluaran yang dirasakan oleh semua masyarakat, pengeluaran masyarkat pada umunya digunakan untuk kebutuhan pokok seperti pembangunan atau renovasi rumah. Mayoritas rumah masyarakat di Desa Mojoayu adalah rumah semi permanen. Perubahan pengeluaran masyarakat juga dilakukan untuk membeli sepeda motor karena rata-rata masyarakat di Desa Mojoayu sebelum keberadaan industri pengolahan lida buaya belum mempunyai sepeda motor.

Masyarakat di Desa Mojoayu belum terlalu mengenal investasi jangka panjang, sehingga pengeluaran terbanyak masyarakat berfokus pada kebutuhan bersifat tersier. Perubahan kondisi pengeluaran yang yang terjadi pada masyarakat di Desa Mojoayu Kecamatan Plemahan Kabupaten Kediri sesuai dengan penelitian yang dilakukan oleh Listiani (2018:41) yang menyatakan bahwa keberadaan industri berpengaruh pada perubahan struktur ekonomi terutama pendapatan dan pengeluaran.

\section{KESIMPULAN DAN SARAN}

\subsection{Kesimpulan}

Berdasarkan hasil penelitian dan pembahasan yang telah dikemukakan, maka dapat ditarik kesimpulan sebagai berikut :

1. Industri pengolahan bekicot PT. Keong Nusantara Abadi secara karakteristik yang membedakan dengan industri lain terletak pada alasan pemilihan lokasi industri di Desa 
Mojoayu Kecamatan Plemahan Kabupaten Kediri, dan sitem kerjasama antar masyarakat dalam kegiatan budidaya bekicot

2. Dari hasil penelitian didapatkan informasi bahwa selama proses produksi diperlukan 450 ton bekicot hidup. Kebutuhan stock bekicot sangat tergantung dari factor musim serta banyaknya competitor dalam industry tersebut diantaranya beberapa perusahaan di Jawa Timur dan Jawa Tengah yang bergerak dalam usaha yang pengolahan bekicot

3. Pendapatan kaum perempuan di Desa Mojoayu Kecamatan Plemahan Kabupaten Kediri, dinyatakan mengalami kenaikan jumlah pendapatan sebesar 45\% (91 orang kaum perempuan).

\subsection{Saran}

Berdasarkan hasil penelitian beberapa saran yang dapat disumbangkan dari penelitian ini sebagai berikut:

1. Bagi pihak pemerintah terutama pemerintah Kabupaten Kediri, lebih memperhatikan dan memberikan pengawasan lebih pada sektor industri olahan bekicot agar bekicot dapat tetep lestari dan tidak punah.

2. Bagi pihak industri pengolahan bekicot sebaiknya lebih berperan aktif dalam mendukung pemberdayaan kaum perempuan

\section{DAFTAR PUSTAKA}

Hanurawan, Fattah. 2012. Psikologi Sosial. Bandung: PT Remaja Rosdakarya.

Listiani, Suma. 2018. Dampak Industri Pertambangan Minyak Bumi Terhadao Perubahan Sosial Ekonomi Masyarakat di Desa Rahayu Kecamatan Soko Kabupaten Tuban. Skripsi. Surabaya: Fakultas Ilmu Sosial dan Hukum. Jurusan Pendidikan Geografi Universitas NegeriSurabaya.

Nawawi, Imam. 2014. Pengaruh Keberadaan Industri Terhadap Kondisi Sosial Ekonomi Dan Budaya Masyarakat Di Desa Ladagar Kecamatan Margaasi Kabupaten Bandung. Thesis. Bandung : Universitas Pendidikan Indonesia

Reksoprayitno, Soediyono. 2004. Ekonomi Makro. Yogyakarta: BPFE UGM.

Robert H. Lauer. 1993. Perspektif Tentang Perubahan Sosial. Jakarta: Rhineka Cipta.

Sarwono, Sarlito W. 2009. Pengantar Psikologi Umum. Depok: Rajawali Pers.

Sigmi, Sas Budiarta. 2018. Dampak Industri Sarang Burung Walet Terhadap Perubahan Sosial Ekonomi Masyarakat di Dusun Tunggun Desa Tunggunjagir Kecamatan Mantup Kabupaten Lamongan. Skripsi. Surabaya: Fakultas Ilmu Sosial dan Hukum. Jurusan Pendidikan Geografi Universitas Negeri Surabaya.

Soekanto, Soerjono. 2006. Sosiologi Suatu Pengantar. Jakarta: PT Raja Grafindo Persada.

Sudarto Y. 1998. Bekicot. Yogyakarta: Kanisius. Sukirno, Sadono. 2006. Ekonomi Pembangunan Proses Masalah, dan Dasar Kebijakan. Edisi 2. Jakarta: Prenadia Group.

Sztompka, P. 2007. Sosiologi Perubahan Sosial. Jakarta: Prenada Media Group.

Tambunan, Tulus H. 2001. Perekonomian Indonesia. Jakarta: Penerbit Ghalia.

Wirawan, I. B. 2012. Teori-Teori Sosial dalam Tiga Paradigma. Jakarta: Prenadamedia. Data Umum Desa Mojoayu. 2017. 